Fall 2001

\title{
The Impact of Irish Ireland on Young Poland, 1890-1918
}

John A. Merchant

Loyola University Chicago, jmerchant@luc.edu

Follow this and additional works at: https://ecommons.luc.edu/modernlang_facpubs

Part of the European Languages and Societies Commons, Intellectual History Commons, Modern Languages Commons, Modern Literature Commons, Slavic Languages and Societies Commons, Theatre History Commons, and the Translation Studies Commons

\section{Recommended Citation}

Merchant, John. "The Impact of Irish Ireland on Young Poland, 1890-1918." New Hibernia Review, vol. 5 no. 3, 2001, p. 42-65. Project MUSE, doi:10.1353/nhr.2001.0039.

This Article is brought to you for free and open access by the Faculty Publications and Other Works by Department at Loyola eCommons. It has been accepted for inclusion in Modern Languages and Literatures: Faculty Publications and Other Works by an authorized administrator of Loyola eCommons. For more information, please contact ecommons@luc.edu. c) (†) $\ominus$

This work is licensed under a Creative Commons Attribution-Noncommercial-No Derivative Works 3.0 License. (c) New Hibernia Review, 2001. 


\section{John A. Merchant \\ The Impact of Irish-Ireland on Young Poland, 1890-1918}

William Butler Yeats and John Millington Synge were by far the most familiar Irish dramatists to Polish readers and theatergoers at the turn of the twentieth century, reflecting the larger reputation these two dramatists enjoyed throughout European literary circles. Polish interest in the work of Yeats and Synge hinged on a strong feeling of affinity between the Polish and Irish cultural and political contexts. Extending over a ten-year period, framed by Jan Kasprowicz's 1904 translation of Yeats's The Countess Cathleen and the 1914 performances of that translation, the Polish presentation of the Irish dramatists' work consisted of one stage production of Yeats's and two of Synge's plays. Kasprowicz's translations also brought attention to a number of Yeats's early poems, as did the critical reviews the plays received in the Polish literary press. Though on the whole Yeats had the greater reputation of the two, both dramatists enjoyed critical acclaim among their Polish contemporaries.

It is not surprising that Kasprowicz would choose the Warsaw journal Chimera in which to publish his translation. Since 1901, Chimera had been a champion of high-minded symbolist aesthetics under its editor, Zenon "Miriam" Przesmycki, and featured an eclectic mix of European, Asian, and American literature. By 1904 Kasprowicz was a mature poet, regarded particularly for his sixth volume of poetry Krzak dzikiej róży (The Wild Rose Bush, 1898) and the two cycles of Hymny (Hymns, 1898-1903) which followed. Kasprowicz had also developed a reputation as a dramatist, having published three plays during the years 1891-1900. The translation of Yeats's play, therefore, came from the hand of an artist comfortable in both symbolic poetry and drama. The translation as it appeared in Chimera, unfortunately, did not contain any form of commentary from Kasprowicz or the journal's editors. The only information provided was a postscript, presumably a translation of Yeats's original, which explained the origin of the tale and included a glossary of Celtic names.

It is understandable why Kasprowicz chose to translate this play. The play, which was originally staged in Dublin in 1899 for the Irish Literary Theatre, deals with the symbolic sacrifice of her life by Countess Cathleen for the starving and sinful people of Ireland. Kasprowicz's decision to translate this play suggests a great deal about his development at the time as a poet and dramatist. His 
poetry, by this point, already reflected a degree of tension between the poet and his Old Testament God. As Kasprowicz came from a peasant background and wrote a form of poetry that integrated elements of symbolism with his strong Catholic faith, The Countess Cathleen provided a natural vehicle for his talents and aspirations.

In the play, the people in the Irish countryside suffer from a long and devastating famine. Overwhelmed by poverty and starvation, two Irish peasants, Shemus and his son Teigue, are tempted to sell their souls for gold to two devils disguised as merchants. Against the wishes of Shemus's pious wife, Mary, they take the money and are enlisted by the devils to convince the rest of the peasantry to do the same. Countess Cathleen, meanwhile, returning to the region after a long time away, feels a deep compassion for the peasants' suffering. When they steal food from her garden, for example, she excuses it by explaining, "A learned theologian has laid down that starving men may take what's necessary, and yet be sinless." ${ }^{1}$ When the devils learn of her plan to use her fortune to feed the people of Ireland, they steal her remaining gold and, in the guise of passing merchants, maintain that the attempts she has already made to purchase food for the people have failed. Horrified by the prospect of starving people selling their souls, Cathleen makes a bargain with the devil to barter her soul as a substitute for all the souls of the Irish people they have already purchased. The devils are delighted at their apparent victory, but in the end an army of angels routes the army of darkness, and Cathleen's soul is restored to its rightful owner, "Mary of the seven times wounded heart" in heaven. ${ }^{2}$

Of all Yeats's plays, The Countess Cathleen was the one most revised. Yeats radically changed the structure and content of The Countess Cathleen more than once. The original version appeared in three acts, but Yeats reconfigured subsequent versions into five scenes. He then reverted back to the traditional three-act structure of the original play in its final drafts. It is not clear where Kasprowicz acquired a copy of the play, but his translation faithfully rendered Yeats's play in its original three-act form. It is doubtful that Kasprowicz had access to the other renditions of The Countess, and it is not likely he was expressing his preference for the three-act version of the play by translating that particular version. The three-act form of The Countess, as it turned out, was a starker story in which the Irish peasants were portrayed as being more malevolent, and the text abounded in symbolic elements of darkness and evil. The two sides in this spiritual struggle are clearer than in the other editions of the play and suited the young Polish dramatist's sensibility and style.

1. William Butler Yeats, The Collected Plays of W. B. Yeats (New York: Macmillan, 1934), pp. 20-21.

2. Ibid., p. 50 . 
In many ways, Yeats's play would have struck Polish theatergoers as being very similar to much of the drama of Young Poland, and of Stanislaw Wyspiański in particular. The story of selling one's soul for money echoed the standard tale of the corrupt Polish szlachta, or nobleman. Wyspiański, for example, included this trope in his masterpiece Wesele (The Wedding, 1901). In the play, the ghost of a Hetman, one of many ghosts who appear to the wedding guests, tells a character in the play of the torments he suffers for having taken money from the Muscovites:

$\begin{array}{ll}\text { HetMan: } & \text { You take gold, gold burns. } \\ \text { CHOiR: } & \text { The little Moscow coins burn? } \\ \text { Hetman: } & \text { Every day is hellish for me, Host: } \\ & \text { devils drink my blood; } \\ & \text { they tear at my chest, at my back, } \\ & \text { dog-like creatures, with heads of fire; } \\ & \text { tear at, clutch at my bowels! }{ }^{3}\end{array}$

The Hetman explains that he tried to get rid of the damned coins, but the creatures tormenting him simply pour new ones into his hands. Other plays by Wyspiański that dealt with Polish legends, such as Legenda (The Legend), would have also resonated in the minds of Polish theatergoers as they watched The Countess. Both Yeats and Wyspiański were able to interweave the elements of myth and peasant folklore, thereby lending them a timeless and universal quality. At the same time, in works such as these, both dramatists also succeeded in rooting their plays deeply in cultural and national traditions of Ireland and Poland. The Countess, therefore, would have been a type of symbolic and artistic drama familiar to educated Polish readers and theatergoers at this time.

In rendering Yeats's text into Polish, Kasprowicz mobilized all his talent as a poet and translator. There is no question whether his Polish audience was experiencing the real beauty of The Countess, because Kasprowicz made few changes and generally captured the poetry of the original word for word in Polish. As with Florian Sobienowski's later translation of Synge's The Playboy of the Western World, which took its cue from Wyspiański's peasant dramas, Kasprowicz utilized a peasant dialect to add to the realism of the play without destroying the magic and fantasy of the story. Kasprowicz's familiarity with peasant life in Poland certainly must have helped him in this regard. The only real slip in the translation, albeit a minor one, appears in Act One when Kasprowicz misinterpreted Yeats's use of "wake," as in funeral, to mean "budzić się" (to wake up). Kasprowicz, however, demonstrated his talent as a translator

3. Stanisław Wyspiański, Wesele (Kraków: Wydawnictwo literackie, 1992), p. 141. My translation. 
and made up for such small lapses in comprehension with his ability to capture accurately the humor and pathos of The Countess in Polish. In the second scene of Act Two, for example, one of the devils describes to the other how he sat by the roadside in the form of "a nine-monthed bonyeen" to fool Father John. Using the overall context of the speech, Kasprowicz correctly used the Polish word "swinka" (pig) in his rendition. Therefore, in both the printed and the staged versions of The Countess, Polish reading and viewing audiences were experiencing Yeats as closely as possible to the original.

The exposure of Polish reading audiences to Irish literary artistry did not end with the initial translation of The Countess Cathleen by Kasprowicz. In 1906, five of Yeats's poems appeared in the journal Nasz kraj (Our Country) under Kasprowicz's name. ${ }^{4}$ Three years after its initial publication, Kasprowicz's translation of The Countess Cathleen appeared again in 1907 in his English Experiments in Dramatic Poetry. That same year, Kasprowicz also published an ambitious anthology of translations into Polish of English poetry under the title English Poets: A Selection of Poetry, which contained eight of Yeats's early poems. ${ }^{5}$

While Yeats enjoyed considerable attention in print in Poland, his colleague in the Abbey Theater, John Millington Synge, was the first to have a play appear on the Polish stage. In 1908 the innovative director Tadeusz Pawlikowski produced Synge's The Well of the Saints together with Stanisław Wyspiański's Secdziowie (The Judges) on the stage of Lwów's Municipal Theater. A year after Kasprowicz's version of The Countess was republished in his two-volume collection of English drama titled Masterpieces of European Drama (1912), Synge's The Playboy of the Western World was staged in Warsaw's Polish Theater. Yeats was finally produced on the Polish stage in 1914, with a production of The Countess Cathleen using Kasprowicz's 1904 translation in the government Variety Theater in Warsaw.

It is not clear which of Yeats's poems Kasprowicz translated in Nasz kraj in 1906, but they were probably those included in his 1907 collection, English Poets. Besides Yeats, he included poems by Chaucer, Shakespeare, Blake, Burns, Moore, Byron, Shelley, Tennyson, Browning, Rossetti, and Wilde. Kasprowicz further revealed his familiarity with English literature by adding poems by several minor poets such as Joseph Addison, Thomas Hood, Felicia Hemans, Robert Bridges, Eric Mackay, and William Watson. A short biographical paragraph preceded each poet's section detailing his or her background and major works. The brief paragraph of biographical information on Yeats, for example, intro-

4. I have not been able to locate a copy of these translations.

5. Jan Kasprowicz, Próby angielskie poezji dramatycznej (Lwów: Altenberg, 1912); Poeci Angielscy: Wybór poezyi (Lwów: Altenberg, 1907). 
duced him as "an Irishman by birth and conviction" and as "one of the most vocal leaders of the Celtic movement." Despite this Irish self-identification, or perhaps because of it, Yeats "belongs to the most likeable and talented of modern English poets" for "just like the Gaelic poet Fiona Macleod, he writes in Eng-

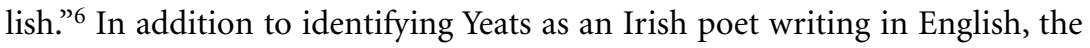
introductory information highlighted his use of Irish folk legends in his plays, his collections of Irish folk tales, and his early interest in painting.

The light poems that Kasprowicz included in this anthology were "The Lake Isle of Innisfree," "Down by the Salley Gardens," "The Sorrow of Love," "When You are Old," "Ephemera," "The Sad Shepherd," "The Madness of King Goll," and "Cuchulain's Fight with the Sea." With the notable exception of the last two, these poems generally involve universal declarations of Romantic love either for a particular location or a person. "The Lake Isle of Innisfree," for example, depicts Yeats's longing for the beauty of his native Sligo, while "When You Are Old" is an appeal to remember past love. All of the poems concern some form of loss, whether it be of love, youth, or in the case of King Goll, his sanity, and Cuchulain, his life. Contemporary critics have suggested that this sense of place and use of Irish mythology added a discretely political element to Yeats's early Romantic poems. ${ }^{7}$ Whether or not Kasprowicz recognized this political element is impossible to say. Based on his own poetry of this period, however, it would seem probable that Kasprowicz valued Yeats's work primarily for its folk mysticism and its use of nature.

Kasprowicz for the most part faithfully rendered Yeats's originals in his Polish translations. He maintained the general structure of the original poems, as well as Yeats's rhyme scheme. The alterations Kasprowicz did make generally were minor shifts in line or stanza construction, or as in the case of "Down By the Salley Gardens," the addition of quotation marks to make explicit the dialogue implied in the original. Only in two poems, "The Lake Isle of Innisfree" and "When You Are Old" did Kasprowicz make changes that suggest the Polish poet was inserting his own persona into the poems. For example, in the former poem, whereas Yeats begins somewhat stiffly "I will arise and go now, and go to Innisfree," Kasprowicz exclaims enthusiastically "Hej zerwe sie, zerwe, do Innisfree polece" ("Hey I will start up, take wing, to Innisfree I will fly"). ${ }^{8}$ The addition of "hej," though admittedly minor, has the effect of relaxing the poem and giving it a folk coloration that was not present in the original. In "When You Are

6. Kasprowicz, p. 437. My translation.

7. See the introduction to William Butler Yeats, Poems: Selections (New York: Woodstock Books, 1994).

8. Kasprowicz, p. 438. My translation. In the final stanza he even adds an exclamation mark after Hej! 
Old," moreover, it is possible to read in Kasprowicz's translation a dimension of religious feeling that did not exist in the English version. In Yeats's original the poetic voice, presumably addressing an old lover, asks her to recall her former beauty and their failed love when she reaches old age. When the original is placed next to Kasprowicz's translation, the difference is striking. Yeats's original stanza is given first, then Kasprowicz's translation and an English rendition of the Polish.

How many loved your moments of glad grace,

And loved your beauty with love false or true;

But one man loved the pilgrim soul in you,

And loved the sorrows of your changing face.

Jak wielu ongi kochalo ten boski

Urok, a tylko jeden kochal wiernie

Pielgrzymią duszę w tobie i te ciernie,

Które ci żlobia czolo-ciernie troski.
How many once loved that heaven-born beauty, but only one love was faithful to your pilgrim's soul and the bramble, which furrowed your brow—sorrow's thorn. ${ }^{9}$

Although Kasprowicz's is a faithful and admirable translation, it differs from the original on a noticeable qualitative level. In the English version, the poetic subject's beauty is innate. In Kasprowicz's Polish translation, however, there is a noticeable use of the religious imagery of Christian mysticism-for example, the reference to "sorrow's thorn." Clearly, in poetry, that most difficult of genres to translate, Kasprowicz could not always render exactly Yeats's genius. Being a poet, therefore, he did the next best thing; he created beautiful poems in Polish by way of his translations.

The overall tone of the poems translated by Kasprowicz is that of personal sorrow. Even the poems about King Goll and Cuchulain are concerned with individual tragedies. Such self-absorbed poetry was certainly popular with the poets of Young Poland. Many so-called neo-Romantic poets, moreover, still sensed a strong tie between the personal and the political. In Polish Romantic poetry a half-century earlier, for example, poets' expressions of longing or heartbreak often couched references to the political situation of the country. While this tendency might not have been as strong in 1907, the Polish reading public remained adept at reading between the lines.

Tadeusz Pawlikowski, however, effected a clearer juxtaposition of the social contexts of Poland and Ireland by staging together Wyspiański's The Judges and Synge's The Well of the Saints in Lwów's Municipal Theater on November 11, 1908. ${ }^{10}$ There is, unfortunately, no extant translation of Synge's play, nor do

9. Kasprowicz, p. 440. My translation.

10. Stanisław Wyspiański, Dziela zebrane, 15, 3, (1958), 219. 
there appear to be any reviews of the performance. Alfred Wysocki in his 1958 memoir The Last Half-Century, however, recollected translating several Scandinavian dramas, as well as one by Synge, for Pawlikowski at this time. In describing his approach to his translations, Wysocki revealed Pawlikowski's intense attention as director to all aspects of the play's production. "Writing," he recalled, "I repeated each sentence out loud to myself." "Despite that," he then continued, "Pawlikowski would interrupt every so often during the reading of my translation saying, 'It seems to me that that word should be moved, or changed, or thrown out altogether' - and he was always right." "1 The 1908 production was most probably the premiere of both plays in Lwów, as the Polish playwright had completed The Judges on his deathbed a year earlier in 1907 and The Well had been staged a mere three years earlier in Dublin.

Much as in Wyspiański 's Klatwa (The Curse), The Judges was adapted from a newspaper story of a real-life event that the playwright raised to a artistic level. Set in a small, backward Polish village, the plot involves the murder committed by one member of a family of Jewish innkeepers and his resulting tragic fate. Synge's play, like all his plays, takes place in the countryside, and is a biting comedy about a married couple, who are blind beggars regaining their sight at the hands of a passing saint and not liking what they see in each other. Both playwrights, furthermore, used a strongly stylized peasant dialect to characterize the people living in the countryside. While there is no contemporary evidence of the quality of these performances, Tymon Terlecki has claimed recently that The Judges was incorrectly staged at this time as a realistic drama, when it should have been done as a Greek tragedy. ${ }^{12}$ It is significant that two such playwrights who drew so heavily on peasant life in their own countries would premiere together on the same stage. This was undoubtedly what novelist Stefan Zeromski had in mind when he declared in his 1915 article "Literature and Polish Life," that "J. M. Synge is so similar to Wyspiański!"13

Synge next appeared on the Polish stage four years later on November 12, 1913 with a production of The Playboy of the Western World in Warsaw's Polish Theater. Florian Sobienowski, who had been living in London and was the primary translator of George Bernard Shaw into Polish, did the translation, which also appears to have not survived. ${ }^{14}$ Under the capable direction of Arnold

11. Alfred Wysocki, Sprzed pøł wieku (Kraków: Wydawnictwo literackie, 1958), p. 222. My translation.

12. Tymon Terlecki, Stanisław Wyspiański (Boston: Twayne Publishers, 1983), p. 45.

13. Stefan Zeromski "Literatura a życie polskie," w Programy i dyskusje literackie okresu Młodej Polski, ed. Maria Podraza-Kwiatkowska (Wroclaw: BN, 1977), p. 709. My translation.

14. Arnold Szyfman, Labirynt teatru (Warzawa: Wydawnictwo Artystyczne, Filmowe, 1964), p. 158. My translation. 
Szyfman, who was much influenced by Western drama and by such innovative directors as Konstantin Stanislavsky, The Playboy was performed a total of eight times. According to a review of the performance by theater director and literary critic Jan Lorentowicz, later published in the second volume of his series of books titled Twenty Years of the Theater, Sobienowski "Wyspiańskized" Synge's play in his translation. He did so by "adding highlanders and Hungarian soldiers to the text, a certain rhythm, and often whole expressions from Wyspiański." ${ }^{15}$ While agreeing that Sobienowski did utilize a highlander accent such as that spoken in the Tatra Mountains, Irena Sławińska has suggested that Sobienowski's inspiration was Kazimierz "Przerwa" Tetmajer's In the Rocky Highlands, rather than that of Wyspiański. ${ }^{16}$ These tales of bandits, shepherds, and ruffians were set in the Tatras and employed a mountain dialect. Whatever its source, the attempt marks Sobienowski's awareness of his audience at home and of recent developments in Polish literature.

The plot of The Playboy, which is in three acts, involves the appearance of Christy Mahon, a timid young man in the public house of Michael James Flaherty and his daughter, Margaret, in a village on the coast of Mayo. In Act One, Margaret, or Pegeen Mike as she is called, is running the public house and talking with Shawn Keogh, who is trying to convince her to marry him. When Christy first enters, he is a suspicious, fearful young man, and Pegeen Mike wants to drive him off. When he confesses, however, that he killed his father and mercy should be taken on him, the attitudes of everyone in the public-house changes. Michael James offers Christy a job as a farm hand, and Pegeen Mike falls in love with him. The act ends with the sharply ironic line, "I'm thinking this night wasn't I a foolish fellow not to kill my father in the years gone by." 17 In Act Two, all the village girls and the Widow Quin come to hear the tale of Christy's awful deed. With each telling Christy becomes bolder and surer of himself. Pegeen Mike, jealous of the other women, tries to warn Christy about not trusting the others. While she is gone, however, Shawn Keogh and the Widow Quin attempt to bribe him to leave in order that Shawn can marry Pegeen. Christy refuses, but upon the sudden appearance of his father, he begs the Widow Quin to hide him.

In Act Three, Christy reaches heroic stature by winning all the local sports competitions, only to be confronted by the reappearance of his father. Exposed as a fraud and a liar, Christy lashes out violently and "kills" his father again in order to maintain the respect of the village and the love of Pegeen Mike. The deed, however, strikes the entire village as a mere brutal act, and they tie him up.

15. Jan Lorentowicz, Dwadzieścia lat teatru, Vol. II (Warzawa: Hoesick, 1930), p. 196. My translation.

16. Irena Slawińska, Wśród mitów teatralnych Młodej Polski (Kraków: Literary Publishers, 1983).

17. John Millington Synge, The Complete Plays (New York: Vintage, 1960), p. 30. 
Christy's father appears for the third time, rescues Christy from the villagers, and leaves cursing them. Pegeen Mike, realizing what she has lost, closes the play with the lines "Oh my grief, I've lost him surely. I've lost the only Playboy of the Western World." 18

Lorentowicz in his review of The Playboy immediately made the connection to Wyspiański. "The Polish Theater," he began, "showed in Warsaw one of the most original works of art that we have been given since the time of The Judges, The Curse, and The Wedding." ${ }^{19}$ Perhaps alluding to the same problems Tymon Terlecki thought had flawed the productions of The Judges, Lorentowicz thought the Polish actors had performed Playboy incorrectly. Rather than make the text more comprehensible to the Polish audience, Lorentowicz felt the director and the actors mixed up the stylized language in such a way that the audience doubted what they were seeing was truly what the author had intended. A greater problem, however, was that "the actors performed the drama entirely realistically."20 "They looked for the tragic tones of Wyspiański," Lorentowicz complained, "but meanwhile Synge himself called his work a comedy and treated the subject with bloody irony, even to the point of distaste." 21 This mistake was of great importance to the audience's understanding of The Playboy, for they ended up leaving the theater "thoroughly disturbed."22 "The Polish Theater changed Synge's irony," he pointed out, "into brutality, wounding the sensibilities of the viewers with a brutality so great that its symbolism was reduced to only a few perceptible phrases."23

Analyzing the performance of the play act by act, Lorentowicz found greatest fault with the first act of the play. Continuing in much the same vein as he began his review, he criticized the first act as being "the falsest" because it was "carried out in a dreamily-slow tempo, lowered in tone by an entirely naturalistic style of acting." ${ }^{24}$ After summarizing the plot of the first act, Lorentowicz returned to this fundamental flaw in the Polish Theater's performance. Asking the question whether the motif of patricide should be taken ironically, he continued, "we know that ... there are allusions of Ireland's attitude to England." This interpretation, as well as attributing Christy's brutal actions to the peasant world, however, in his opinion did not provide a satisfactory answer. "The entire act," Lorentowicz emphasized referring to Act One, "should not be taken
18. Ibid., p. 80 .
19. Lorentowicz, p. 196.
20. Ibid.
21. Ibid., p. 197.
22. Ibid.
23. Ibid.
24. Ibid. 
literally, as did the actors of the Polish Theater." "By posing ourselves the impatient question: 'what next?"' he concluded, "we realize by his [Christy's] shout that something completely different is happening in the drama than what we saw realized on the stage." ${ }^{25}$ It was the Polish Theater's failure, in Lorentowicz's view, to grasp this gap between the literal action of the play and its ironic message that made it such a disappointing production. The author's true "ideology" is revealed, he felt, when Christy's father appears in Act Three and exposes him as a sham hero. "According to the law, his crime would be very grave," Lorentowicz explained, "but in light of the requirements for heroism in the countryside, Christy's deed is not a deed." "Here Synge reveals himself as a truly great poet," he then added, "Christy's so-called deed is only a common, awful crime. When he spoke of the deed, they all listened to him ... as if to a story from a fairy tale. For them there did not need to be a murder, only—heroism." ${ }^{26}$ The other peasants' violent reactions to Christy's base crime struck Lorentowicz as being somewhat similar to the ending in Wyspiański's The Curse. In this play, a village worn down by a terrible drought demands the sacrifice of the children of the local priest's mistress to cleanse the village of its sins and thereby end the drought. Synge's use of irony, however, allows for Christy to assume truly the role of the hero, or playboy, and rescues the play from becoming merely brutal.

Besides its rare combination of hellish laughter, poetic fantasy, and freshness of thought, Lorentowicz considered The Playboy in the end to be "above all the voice of a living, new talent." "There must be something from a fairy tale," he concluded, "something from a bloody legend; it must be delivered by all performers strictly according to the arranged stylization." ${ }^{27}$ Slawinska claims that this kind of comedy and the type of character presented in Christy were both unprecedented in Poland..$^{28}$ Szyfman, however, in his recollections of the theater years later claimed that the eight performances of the play "received great press, which I read with true satisfaction." The problem, he felt, was not with the performers, but with the audience. While the critics showed great perspicacity in their reviews, the Polish theatergoing public apparently failed to appreciate the play. "They had been demoralized for a decade by the repertoire of the Variety and Summer Theaters," Szyfman explained, "and even such tremendous acting ... could not bring them to admire these valuable and interesting productions and performances." ${ }^{29}$ Regardless of who is to be believed, Lorentowicz or Szyfman, it seems clear that Synge's play was not a popular success.

\footnotetext{
25. Ibid., p. 199.

26. Ibid., p. 200.

27. Ibid., p. 202.

28. Slawinska, p. 14

29. Szyfman, p. 158.
} 
Just over a year later, on December 19, 1914, the government-sponsored Variety Theater staged Kasprowicz's translation of The Countess Cathleen. The production apparently also included a "clever" prologue in verse by the director, M. Tatarkiewicz. There is no evidence to indicate the total number of times the play was performed, but two extant reviews of the play, one by Lorentowicz on December 19 and another by a W. Poplawski on December 21, suggest that there were at least two performances. Lorentowicz begins his review with a paraphrase of Yeats's poem "The Sad Shepherd." The poem describes a man "whom Sorrow named his friend" who tells his troubles to a seashell because no one will listen to him, only to find that the shell "changed all he sang to inarticulate moan / Among her wildering whirls, forgetting him."30 "With strange stubbornness," Lorentowicz then explained, "that ballad came to mind during the premiere in the Variety." ${ }^{11}$ While the director and actors succeeded in presenting an "exquisite Irish legend, dramatized by a great poet," the Warsaw audience was not able to appreciate such a work. "Unfortunately," Lorentowicz maintained, "the undertaking, which by itself is difficult and requires strenuous effort, became even more risky by appearing in a theater whose ears are stopped up with the gray repertoire of bourgeois prudery and which truly hates poetry." ${ }^{2} 2$ Because of the Warsaw audience's distaste for poetry, and the actors' tendency to read the poetry as prose, he continued, the intended effect of the play was lost. "The fairy tale tone of the play," Lorentowicz pointed out, "became under such conditions something irritating because it was devoid of the rhythm and magic of legend." Presented in gray realism, the wonder of poetry became "a theatrically empty conch shell-the words of the poet's song 'changed to inarticulate moan."”33

Lorentowicz gave greater praise to the efforts of the Variety Theater in producing The Countess. "The directors of The Variety must be congratulated," he noted, "that they had the courage to acquaint the wider general public with one of the best poets in Ireland today." ${ }^{4}$ In explaining Yeats's position in the Irish Literary Revival, Lorentowicz again invoked the name of Wyspiański. "Similar to our Wyspiański," Lorentowicz explained, "(with whom he shares a kinship for fantasy and a love for native legends), Yeats devoted himself for a time to painting, which he gave up on becoming entirely absorbed in lyrics and epic songs stemming from folk traditions." 35 The legend upon which The Countess is based,

30. William Butler Yeats, W. B. Yeats: Selected Poetry, ed. A. Norman Jeffares (London: Macmillan, 1966), p. 3 .

31. Lorentowicz, p. 192.

32. Ibid., p. 193.

33. Ibid.

34. Ibid.

35. Ibid. 
Lorentowicz felt, was a universal one. Poland had its own tradition with such tales. "The monograph of our Twardowski," he pointed out, "occupies a unique place in the history of such bargains with the devil." Because the legend is so familiar, however, "only a great poet could touch it today with success." ${ }^{36}$ Yeats's play did succeed, he believed, because it "was not relenting for even a second with originality and freshness of fantasy-that is witness of a great talent indeed." Though limited in its technical ability to realize such a poetic vision, "we see a good will and that—in today's hard times—counts for a lot." ${ }^{77}$ On the whole, the majority of the problems with the performance in Lorentowicz's view appear to have been related to stage production and the actors' unfamiliarity with this type of poetic drama.

Poplawski's review of the play, which appeared under the title "The Variety Theater" in a daily newspaper two days later, was generally a glowing one. "The Countess Cathleen has been revealed to the world," he began, "a land of the most beautiful legend that humanity possesses." ${ }^{8}$ Poplawski, too, appreciated the high poetic quality of the play. Characterized above all by a "great and pure simplicity," Yeats's play is "clear and very expressive" because it is devoid of "strangely intricate oriental symbolism." ${ }^{39}$ The play in Poplawski's view, was ultimately a kind of tale. "This is not a versified fantastic drama, neither is it a conceived legendary spectacle - it is a fairy tale, in which there is nothing earthly — though everything is so straightforward, human and not over-fantasized." "How clear and sublime," he added, "must be the mind of the poet who created this work." 40

Poplawski echoed the praise of Lorentowicz. He not only congratulated the Variety Theater for being brave enough to stage such a play, but he also noted its value to contemporary society. "It is a pure spring of poetry," he asserted, "the truest and noblest teacher in these difficult and arduous times." ${ }^{11}$ Poplawski, like Lorentowicz, considered this a rather difficult play to stage. The role of the Countess, moreover, he felt to be particularly difficult. "There is no place for dramatization, " he declared, "nor for actor's games ... one must seize the internal tone of Cathleen, that is conquer the role of Cathleen." In his opinion, the actress in the Variety's production, Janina Szylling, "was Cathleen as Yeats wrote her." ${ }^{2}$ The portrayals of the devils added additional scenic value to the

36. Ibid., p. 194.

37. Ibid., p. 195.

38. W. Poplawski, “Teatr Rozmaitości,” Gazeta Poranna Dwa Grosze, 810 (352), 21 December, 1914, p. 352. My translation.

39. Ibid.

40. Ibid.

41. Ibid.

42. Ibid. 
production. In a similar vein to Lorentowicz's, however, Poplawski's negative comments about the performance related to its pacing and the nature of its costuming. "This will not be difficult [to remedy]," he concluded, "for we are convinced of the theater's good will." ${ }^{43}$ Poplawski, too, mentioned the prologue by the director, Tatarkiewicz, stating that it "tied Yeats's play to our times. Indeed, we are not strangers to hunger, cold, and the poor fate of a fallen people." 4 Poplawski closed his review by pointing out that Kasprowicz's version had the virtues of all his translations: "strong language, the spirit of the original, and an understanding of the value of words spoken from the stage." 45

While Yeats's and Synge's work may not have always been understood by Polish reading and theatergoing audiences, it seems clear that they did have a strong point of comparison in the figure of Stanislaw Wyspiański. In his work, Poles had become familiar with a poeticized form of drama that treated both contemporary and historic topics with a blend of legend, peasant culture, and fantasy. This strong native influence, unfortunately, appeared to have also been the cause of much of the difficulty in transporting Yeats and Synge to the Polish stage. Whereas the work of all three playwrights overlapped in a number of areas, the strong sense of tragedy and the epic scale of Wyspiański's theater meant that his plays had to be staged differently. Polish audiences certainly could relate to the stories in the Irish plays, but Synge's use of irony and Yeats's poetic vision presented them with a new kind of theater. As the reviews of the plays suggested, however, the greatest problem Polish audiences faced in receiving the Irish plays was that they did not match it with their developing tastes. With the political and social situation becoming increasingly unstable as World War I approached, it seems that Polish theater-going audiences preferred more traditional commercial theatrical fare to so-called "artistic" works.

The majority of these plays were performed in Warsaw just prior the First World War. None of the plays or translations were done in Krakow, where Wyspiański lived and much of the early creative energy of Young Poland had originated. Roman Taborski suggests that the breakthrough for theater in Warsaw was both an aesthetic and a political one. ${ }^{46}$ The 1901 production of Stanisław Przybszewski's The Golden Fleece marked a break with the conservative dramatic theater. The 1905 Russian Revolution also constituted a political break, as government censorship ceased to be as stringent as it had been before.

43. Ibid.

44. Ibid.

45. Ibid.

46. Roman Taborski, Teatr polski w latach 1890-1918: zabór rosyjski (Warszawa: Panstwowe Wydawn. Nauk., 1988). 
Józef Kotarbiński, moreover, the one-time director of the Kraków Municipal Theater, in 1909 became the literary director of all the government-sponsored Warsaw theaters. Kraków had not, of course, completely lost its importance as a theatrical center by 1913-14, as most of the new plays that premiered in Warsaw had been first staged in the former capital. Yet Warsaw was clearly increasing in importance to the Polish stage. After Polish independence in 1918, Polish theater would continue to grow and consolidate under the artistic direction of such distinguished figures in the Polish theater as Arnold Szyfman and Leon Schiller.

Although he was not the first to express interest in Irish writers, the true expert on Irish-Ireland was Adolf Nowaczyńnki. Nowaczyński (1876-1944), a wellknown satirical dramatist and literary critic, revealed an intimate knowledge of Irish culture, history, and politics in several articles he wrote on the Irish cultural and literary revivals. Nowaczyński not only displayed both a consistent and deep familiarity with even the most obscure names in the Irish literary scene, he also recognized a natural link between the cultural movements then taking place in Poland and Ireland. These were not mere similarities, for in his eyes the Irish were "Poles of the Western World."

The extent of Nowaczynski's appreciation of Irish literature were revealed in two articles, one written before and one after World War I. The first essay, published in 1907 in the journal Świat (The World), appeared under the title "Odrozenie Erynu" ("The Rebirth of Erin"). The later publication, "Teatr irlandzki" ("The Irish Theater"), took the form of a chapter in his 1918 collection of literary essays titled Szkice literackie (Literary Sketches). Both articles focused specifically on the cultural and literary developments that had been taking place in Ireland at the turn of the century, though the latter article dealt with drama in greater detail. Another article which fell in between these two, "Polska w literaturze angielksiej" ("Poland in English Literature"), published in 1915 in Sfinks, was less interesting for what it said about Irish literature than for what it revealed about Nowaczyński's ever-increasing drift to Poland's political right. As one of Young Poland's most fearless satirists who loved nothing more than attacking bourgeois philistinism, Nowaczyński would seem an odd choice to write on Irish literature. In the manner in which he addressed Irish literature and related it to his Polish reading public, however, he remained true to his satirical nature.

Nowaczyński's childhood as the son of an official in the Austrian judiciary in Kraków seemingly had a great deal to do with his later development as the enfant terrible of Young Poland. Forbidden by his parents to participate in stu- 
dent political groups while a student at the Jagiellonian University, during the years 1894-95 Nowaczyński developed a taste for literature and joined a literary circle with some other students. Not only was he soon reading the latest Polish and European writers, but by 1898 he was corresponding with an infamous figure in Polish modernism, Stanisław Przybyszewski. A well-recorded instance of the young Nowaczyński's restless temperament occurred after the assassination in Geneva of the Austro-Hungarian Empress, Elzbieta, by the Italian anarchist Luccheni in 1898. According to reports, upon learning of the event Nowaczyński stood up in a crowded Krakow café and declared "Vive l'anarchie!"47 Following this scandal, for which his father publicly denounced him in the press, Nowaczyński added "Neuwert" (new value) to his name to separate himself from his family.

Feeling oppressed by Krakow's conservatism, Nowaczyński permanently settled in Warsaw in 1904, where he developed into a skilled satiric playwright and literary critic. He began his literary career by writing satires, for example, on the Polish modernists in Krakow titled Malpie zwierciadto (Monkey's Mirror, 1902). About this time Nowaczyński began writing plays, many of which dealt with specific historical figures, such as Frederick the Great or the Polish general Kazimierz Pulaski. His dramas were "not bad, but they were not dramas," the critic Wilhelm Feldman observed years later. "They were the type of stories," he then explained, "in which the author expresses his opinions, not the action; that is, spoken polemics, invective." 48 Nowaczyńnki continued writing plays until the First World War. During this first period of his professional life he also began a long career as a much-feared literary critic, while publishing several articles and a book on Oscar Wilde.

In spite of his book on Wilde, it is unclear why or how Nowaczyński decided to write about the Irish Cultural Revival in 1907. His article, "The Rebirth of Erin," moreover, displayed a familiarity with Irish politics, history, and culture of some depth. Written in two installments, Nowaczyński focused on the efforts of the Gaelic League at reviving the dying Irish language and infusing Ireland with a renewed sense of national identity. The first part of the essay consisted of a scathing attack on the "mania" of politics in Ireland, most notably the "Irish Brigade," or the Irish party in parliament at the time, and the Irish church. The second part of the essay focused on the cultural work of the Gaelic League and Revivalist intellectuals. "In these anti-metaphysical times," Nowaczyński maintained, "a wonderful occurrence has taken place of which philosophers and

47. Artur Hutkniewicz, "Adolf Nowaczyński: 1876-1944," Literatura okresu Mlodej Polski, Ser.V, in Kazimierz Wyka, ed., Obraz literatury polskiej XIX i XX wieku (Warsaw: PWN, 1967), p. 360.

48. Wilhelm Feldman, Wspólczesna literatura Polska, 1864-1923 (Warszawa: Gebethner and Wolff, 1923), p. 305. 
theorists of the idea of statehood for twenty years had not dreamed, the rising from the ashes of denationalization of the emerald phoenix of Celtic Ireland." ${ }^{9}$ At the beginning he gave his readers some idea of how this related to Poland. "This is one of those rare spectacles on a great scale which one should exalt and enjoy, cite and research," he explained, "and draw from it optimism, bravery, and belief in the intervention of the unseen." ${ }^{50}$ Poles had something to learn from the Irish, he felt, because for "over 700 years they [the Irish] have suffered under torture and oppression, next to which our XIX century pales and shrinks in size like a cloud disappearing over the horizon." ${ }^{11}$

Beyond his opening salvo at "almighty Albion" for poisoning Ireland with the English language, Nowaczýnski did not dwell on the evils of British imperialism. Rather, in the first section he concentrated on attacking the Irish evils. From this point on, Nowaczyński was strikingly similar in tone and content to D. P. Moran in the Leader and other "nativist" Irish-Irelanders. ${ }^{52}$ In Nowaczyński's mind, Irish politics in the nineteenth century, beginning with O'Connell and including the contemporary "Irish Brigade" in parliament at the time, had cajoled and misled "poor Paddy" until he had lost what was most essential—his language. While Nowaczynski considered the root of the problem, practical or materialist politics, to have afflicted O'Connell and Parnell, he saved his venom for the "West Britons," those "103 shouters and lawyers" in the House of Commons "who are more English than the English themselves." ${ }^{53}$ By placing the fate of Ireland in the hands of these "arrivistes" who scorned its language and folklore, Nowaczyńnki felt, Home Rule would just provide "another English arena of stupidity and useless human business." ${ }^{24}$ This focus on England and English concessions, such as Home Rule, Nowaczyński felt only contributed a moral and psychic dimension to the already existing political bondage. Much in the same vein as Moran, or perhaps Arthur Griffith in Sinn Fein, Nowaczyński considered the reliance on a British solution as having a further corrosive or internally Anglicizing effect on Irish culture. A key difference from his Irish counterparts, however, was that Nowaczyński viewed the poor besieged peasantry as being led further astray by alcohol and the "spiritual dictatorship of the clergy." ${ }^{5}$ Nowaczyński clearly thought that the Irish politi-

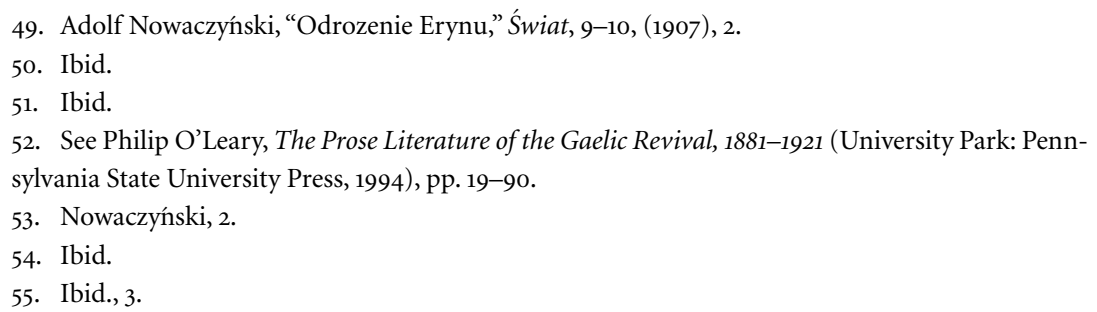


cians were selling Ireland out, and he labeled the members of the Irish party as "ambitious materialists." ${ }^{\text {" N }}$ Nowaczyński concluded this first installment with a stunning sustained metaphor of the Anglophiles destroying Ireland, which by virtue of its acidity deserves attention:

[T] hat English cultural club, reading the penny dreadfuls imported from London, eating sandwiches, Durham filets, York ham ... those posing as WestBritons and despising those possessing his language, his treasures and traditions ... as abstractions, and to whom he neither gives York ham to eat nor porter to drink. $^{57}$

Language such as this would certainly have warmed Moran's satiric heart.

Nowaczyński's tone and attitude changed markedly, however, in the second installment of "Rebirth." The Gaelic League received in this second essay as much praise from him as the "Irish Brigade" had received criticism. While the "mania" for politics, in his view, had corroded Ireland's sense of self, the decision of the Dublin intellectuals for the "absolute separation of nationality from the politics of the nation and from the religious question" struck Nowaczyński as the ideal posture. Unlike the West Britons he described above, recovering Ireland's ancient heritage from political agitation and London bourgeois political values was the primary concern of the Gaelic League. Taking their cue from the larger European pan-Celtic movement, Nowaczyński observed, the members of the Gaelic League sought to preserve the Irish language, and so "the mud huts, bogs, and glens became the goal of the first participants in the revival." 58

Nowaczyński revealed a deep familiarity with a wide range of key Irish cultural figures and Celtic experts. Not only did he know about the first president of the Gaelic League, Douglas Hyde, but he also seemed well acquainted with such Celtic scholars as Kuno Meyer and Whitley Stokes. In addition to relating the early history of the Gaelic League, Nowaczyński proceeded to discuss in detail the efforts to save the Irish language. "In 1893 the League was founded on the smallest of foundations," he noted, "in 1896 80,00o copies of [O'] Growney's primer were sold, in 1897 there already were 240,000 copies, so that by 1905 it would reach half a million copies." 59 Nowaczyński was referring to Father Eugene O'Growney's basic instructional books on the Irish language, for which actual sales were significantly lower than he claimed. ${ }^{60}$ Whether this overstatement was the result of a misleading source, Nowaczyński's unfamiliarity with

56. Ibid. The italics are Nowaczyński's.

57. Ibid. The ellipses, except the one in brackets, are Nowaczyński's.

58. Ibid., 9 .

59. Ibid.

6o. O'Leary, p. 13. For the year 1908, O'Leary cites O'Growney's most basic text as the biggest seller at 5,645 copies. 
the details, or a deliberate attempt to propagandize his readers, the basic assertion remained valid. Nowaczyński exulted in the emergence of several Gaelic newspapers and magazines, a funded Gaelic theater in Dublin, and the enthusiasms of traditional and authentic Gaelic costume, music, and dance. Nowaczyński welcomed the emergence of episcopal pastoral letters in two languages, Irish and English, for "it reveals the power of the rebirth of a language, that even the Church has joined so ideally with the national movement." ${ }^{\prime 1}$ Most significant in his eyes, however, was the Gaelic League's success in expanding the cultural and intellectual sphere in Ireland. By recruiting from the lower classes, Nowaczyński suggested, the Irish could resist the various machinations of the "respectable classes," the indifferent Catholic hierarchy, the jealous Orangemen, the vampiric landlords and police, and, worst of all, the snobbish shoneens who aped anything that came from England. In the end, then, the Gaelic League offered a kind of spiritual and cultural salvation for Ireland, "so that they will not have to sell their birthright for a mess of pottage, for 'Home Rule' with a window to an Anglo-Saxon world and worldview! Erin go bragh!"62

It is not clear where Nowaczyński found his enthusiasm for, or knowledge of, the Irish cause. The Polish press at this time certainly welcomed news of a Catholic country in similar straits as Poland, and if Nowaczyńnki did not have access to such news in Warsaw, he could have easily found it in Galicia, where Catholic sympathies were quite strong. He was, of course, writing from a Warsaw still disrupted by the 1904 Russo-Japanese War and the 1905 Russian Revolution. Though perhaps a bit premature in Nowaczyński's own political development, his article on the Gaelic League had some crossover with the ideas of National Democracy. Roman Dmowski and the National Democrats condemned the Old Polish Respublica for losing sight of Poland's national interest and for diluting its essential Polish core with minorities. While Nowaczýnski praised the unity of the Gaelic League, and singled out such leading Protestant figures as Hyde, he at the same time condemned those Irish shoneens who were selling out Ireland's vital interests to England. In particular, he focused his ire on those who disdained to promote the revival of the Irish language, a defining element of national distinctiveness. As in his plays, Nowaczyński had a message for his audience.

The 1915 article "Poland in English Literature," though not exclusively concerned with Ireland, did contain some interrelated references. When discussing the Anglicization of old Polish families who had settled in England, Nowaczyński complained that "all the average shopkeeper knows about Poland is that we are some kind of altered paraphrase of Ireland, linked in a painful,

61. Nowaczyńnki, 9.

62. Ibid. 
onerous, and inseparable alliance with the 'England' of Russia."63 England assumed, he continued, that Poland was composed of the same motley assortment of economically backward and popery-inclined "duffers, fantasists, loafers, windbags, and drunks" as Ireland, so that the average "Sam or Tommy Bull" immediately took "Home Rule to mean Rome Rule." ${ }^{4}$ In interesting fashion, Nowaczyński then proceeded to draw a parallel between policy of the kulturkampf in partitioned Poland and that of the "holy Orangemen and Dublin chauvinists against that other turbulent Catholic-revolutionary Ireland." ${ }^{65} \mathrm{He}$ clearly viewed the backward state of affairs in Poland and Ireland to be the product of outside interference. The misguided ideas of "culture" and "progress" which deceived the shopkeepers, according to Nowaczyński, stemmed from "the international Jewish Mafia of the liberal press."66 Nowaczyński's antiSemitism was here in full bloom as he suggested that England's real battle at this point was not the war, but an internal battle for "disinfection" so that it could return to rational, enlightened rule at home and in Ireland. It was due to the alien "German" element in England, he charged, that Poland was looked down upon and treated with indifference. Though the article spoke little to the problem of Irish literature, it does reveal how Nowaczyński's political outlook had already begun to change.

It was not until the appearance of his book Szkice literackie (Literary Sketches) in 1918, however, that Nowaczýnski began to discuss Irish literature at any great length. Taken together with the other chapters in the book, which ranged from the influence of Balzac and Shakespeare in Poland to Czech culture and the Belgian Bible, Nowaczyński displayed his extensive knowledge of a wide variety of literatures.$^{67}$ In this essay, unlike his first approach to Irish culture, Nowaczyński was taking a retrospective look at the Irish Revival. "From the time I wrote 'The Rebirth of Ireland," Nowaczyński began "and about the Irish authors W. B. Yeats and George Moore, a few years has passed, but not in my wildest dreams did I suspect that the resurrection of Celtic culture in such a short time would achieve such results." ${ }^{38}$ Politically as well, he explained, Ireland "is making such powerful forward progress in its spiritual development that it

63. Nowaczyńnki, "Polska w literaturze anglielskiej," Sfinks (1915), 60.

64. Ibid.

65. Ibid.

66. Ibid.

67. In this essay, for example, Nowaczyński stresses the need for all Europeans, especially young Poles to read the "Belgian Bible," or La legende et les aventures heroiques, joyeuses et glorieuses d'Ulenspiegel et de Lamme Goedzak au pays de Flandres et ailleurs, because it is an excellent literary work by the small Flemish, and Catholic, nation.

68. Nowaczýnski, "Teatr irlandzki," Szkice literackie (Poznań: Ostoja, 1918), p. 61. I have not found any reference to the works on Yeats and Moore that Nowaczyński mentions here. 
is a double of our nation, these 'Polands of the Western World." 69 After a quick summary of the successes of the Gaelic League, Nowaczynski moved quickly to the primary subject of his essay-Irish drama. "The most powerful proof of the vitality and power of an oppressed nation rising from sleep," Nowaczyński maintained, "is that sphere of art which everywhere is a mirror of the psyche of the race and everywhere is a measure of the intellectual, moral, and organizational power of the nation. That is drama."70 As evidence of this growth in power, Nowaczyński pointed to the changes that must have been witnessed by figures such as Meyer and Father Patrick Dineen, an Irish language revivalist, resulting from the Irish revival. Meyer had lived to see his books reviewed favorably in the Times. Father Dineen, moreover, had seen around him "such activity, such life, such strength coming from the earth that it altered, formed, and emboldened a fatherland that was once a lazy, desperate, drunken ... and utterly depraved people under the baton and perfidious, vampiric politics of John Bull." ${ }^{\prime 1}$

The most significant change in Nowaczyńnki's view, however, was that of the growth from the original three founders of the Irish Literary Theatre in 1899 (Yeats, Lady Gregory, and Edward Martyn) to the some thirty authors who were writing for the Abbey Theatre at the time. Nowaczyński again displayed a surprisingly deep knowledge of Irish literature, as he was able to list those lesser-known names, "as if taken from Ossian such as Seumas O'Cuisin, Padraic Colum, Seumas MacManus, and Thomas MacDonagh." ${ }^{72}$ He even included a sideward glance at the "strictly European" George Bernard Shaw, who evinced feeling for his Irish heritage in his play John Bull's Other Island. Nowaczyński pointed out the "social" character of these Irish playwrights was not simply political, but nationalistic. Closer to home as a satirist and playwright, he explained that the reason why there were so many satirists and ironists among the Irish dramatists was that they were attempting to change Ireland from the land of "dreamers and saints' ... and 'oafs and sluggards"' into that of "strong, creative and living Celts." 73

Although respectful and generous to Yeats's early contributions to the spiritual foundation of this movement, Nowaczyński soon left him behind in favor of newer and younger writers. He preferred this new generation, who "looked reality straight in the face and who not only did not cover their eyes with their

69. Ibid. The part of the quote in single quotation marks is as Nowaczyński originally wrote it in English.

7o. Ibid.

71. Ibid.

72. Ibid., p. 62. I have been able to identify O'Cuisin as James H. Cousins, an original member of William G. Fay's Irish National Dramatic Company formed apparently in 1902. See Hugh Hunt, The Abbey: Ireland's National Theatre, 1904-1979 (New York: Columbia University Press, 1979), p. 35. 73. Nowaczyński, "Teatr irlandski," p. 63. 
hands, but decided to intervene, form, and reform." ${ }^{74}$ In seeming contrast to his 1907 declaration of the separateness of culture and politics, here Nowaczýnski underscored the political value of the new Irish Theater and, more important, its relevance to Polish literature. "The Irish stage," he postulated, "becomes the arena, cathedral, pulpit, the minaret of the muezzin, confessional of the people, and the spiritual parliament of the nation, which does not yet have a political parliament." 75 The affinity between Poland and Ireland from Nowaczyński's point of view was natural and obvious. "All the Irish plays," he continued, "can be translated into Polish, change only the names and bring them to us and they will be lives taken from the Polish psyche." ${ }^{\text {76 }}$ Nowaczyński illustrated his assertion of the affinity between Poland and Ireland by citing five or six new dramatists and their works, such as T. C. Murray's Birthright (1910) George Birmingham's Eleanor's Enterprise (no date), and Lennox Robinson's Patriots (1912). From such plays as these, Nowaczyński posited, "we can see to what degree the Irish are 'Poles of the Western world."'77

The model dramatist for Nowaczýnski was John Millington Synge. Nowaczyński labeled Synge's corpus of plays "as an important, cultural and fruitful thing." 78 While he greatly appreciated Synge's "symbolic satires," Nowaczyński let his true sympathies shine through by calling The Playboy of the Western World "a masterpiece of poetic sarcasm." 79 In the "epoch shattering" staging of the The Playboy in Dublin in 1907, Nowaczýnski drew a comparison to the reaction to Stanislaw Wyspiański's stunning and scandalous play The Wedding in Kraków in 1901. Not only did he consider both playwrights to occupy central places in their respective literatures, but he also felt they both blended idealism and the dying strains of positivism in their work. Nowaczyński admired Synge for his satiric treatment of the reality around him, which allowed him to thrust the brutal reality of Irish peasant life in his audience's faces and pass it off as beautiful, fantastic legend. "J. Millington Synge in his works does not part company with the right of the oppressed or the poor Irish cottage," Nowaczyński explained, "but with a caring, unforgetting, and maternal love he reveals the wounds of this eternally suffering country." 80 In this regard, Nowaczyński regarded Synge as being akin to Dante, as he translated the bitter fury of the nation into a tale of heroism.

\footnotetext{
74. Ibid., 64 .

75. Ibid.

76. Ibid.

77. Ibid.

78. Ibid.

79. Ibid.

8o. Ibid., p. 66.
} 
While Nowaczyński gave much attention to Yeats and Synge, as well as to such other key figures of the Abbey Theatre as Lady Gregory and George Moore, it was a relatively minor figure, George Birmingham, to whom he devoted the last few pages of his essay. In Birmingham's play, General John Regan, Nowaczyński perceived the ideal corollary to the Polish context. A riot broke out during one performance of the play, which ultimately resulted in the beating up of the actors and the burning down of the hotel in Westport where it was being staged in $1914 .^{81}$ In this play Nowaczyński had found his ideal. The play tells the story of a rich American who arrives at the hotel in the sleepy town of Ballymoy in Mayo and announces that he is searching for the birthplace of General John Regan, who he claims was born there. Though none of the townspeople have heard of the General, the clever and hopelessly-in-debt Doctor Lucius O'Grady convinces them to pretend that they had heard of him in hopes that the visitor will show his gratitude in American dollars. In the end, however, the American reveals the truth that there is no General John Regan and that he had made him up because the town struck him as being so backward and boring.

Nowaczyński noted two key facts about the play. First, he pointed out that it was first staged in Dublin by a Pole, Kazimierz Dunin-Markiewicz, the husband of Countess Markiewicz. Second, he drew comparisons to his own play Nowe Ateny (New Athens), which he claimed received a similar, though not as violent, response from the audience. More to the point, however, Nowaczyński underscored the crossover of satire and life in Birmingham's play, which he felt to be the ultimate goal of theater. It was, in part, because of Irish dramatists' fear of revealing the ugly truths about their country that Ireland was still so looked down on by the world. Why do you think, he asks, South Africa got Home Rule so quickly?
But you must know in the end, you (as the publicist Kelley says in the Leader) Poles of the West, one thing. The little seaside town of Westport witnessed final- ly the ultimate satiric triumph, one which can be envied them ... The hotel was even demolished in which for once the truth, and not a fable, about the Irish nation was staged. ${ }^{82}$

In a rather arrogant sense, then, Nowaczyński considered the role of the satirist to be that of uncovering those harsh truths that the nation did not want to acknowledge. Such severity was necessary, he thought, to advance both the moral and material progress of the nation as a whole.

In all three of these essays by Nowaczyński the caustic voice of the brutal satirist shone through. As a Polish critic, "Dr. Z. M.," remarked in a review of

81. See Robert Hogan and Richard Burnham (eds.), The Years of O'Casey, 1921-1926: A Documentary History (Newark: University of Delaware Press, 1992), pp. 121-22.

82. Ibid., p. 70 . 
Nowaczyński's Szkice literackie (Literary Sketches) in 1918, "Nowaczyńnki is not interested in the topic itself." "Each topic is just a pretext," he then pointed out, "so that he can vent his innate restless energy and ever-poisoned thought about our reality." 83

Despite these sharp observations, however, Dr. Z. M. closed his review by stressing the high quality of Nowaczyńnki's criticism and his hope that he would continue to publish such high-caliber work in the near future. Regardless of his political views or intentions, in his treatment of the Irish Literary Revival, Nowaczýnski found a wit and zest for life in the face of terrible inequities similar to his own.

Virtually nothing has been written in the fields of Polish and Irish literature about the cultural relations between Poland and Ireland at the turn of the twentieth century. Irish scholars, meanwhile, have made much of the influence of Japanese dramatic forms on Yeats or French literature on Synge, while their Polish colleagues have carefully noted the impact of French or Scandinavian literature on Kazimier Przerwa Tetmajer or Stanisław Przybyszewski. It could be argued that the Irish literature was merely one of a great number of different national literatures to be imported into Poland by Polish writers and translators with wide-ranging literary interests. This heterogeneity of interests, which ranged from Indian mysticism to Shakespeare to Baudelaire, did preclude the domination of Young Poland by any one foreign source. The impact of IrishIreland on Young Poland, however, reveals a cultural affinity that is both deep and striking between Ireland and Poland at the beginning of the twentieth century.

This cultural kinship between Young Poland and the Irish Revival was most evident in the shared motifs employed by the key figures of each movement. In both Poland and Ireland a renewed interest in the peasantry resulted in new forms of poetry and drama strongly influenced by the speech, music, customs, and folklore of those residing in the countryside. Because of this widespread chlopomania, or peasant mania, it seems logical that Kasprowicz, who came from a peasant background, would choose to translate The Countess Cathleen. Florian Sobienowski, likewise, naturally drew upon the language and set design of Wyspiański's peasant dramas in his translation of The Playboy of the Western World. Polish and Irish writers also employed motifs of the supernatural and legends adapted from local folklore, due to the flexibility and power with which they could reshape them to address larger issues of national identity.

83. Dr. Z. M., "Szkice literackie Ad. Nowaczyńskiego," Romans i Powieść, 33 (1918), 8. 
Reviews of the Polish production of The Countess Cathleen make clear that critics and the theatergoers in Warsaw were open to discussions of national identity, and perceived Ireland as a suffering and oppressed country. Even the appellation "Young Poland" suggested a return to the origins, or a rebirth, of the Polish nation. As both Poland and Ireland by this time had endured more than a century of political nonexistence, legend and myth became an important tool for filling in the cultural void in society and transcending history.

The real significance of this cultural affinity between Young Poland and Irish-Ireland rests in the extent to which Polish writers, such as Nowaczyński, affirmed their own projects in the activities of their Irish counterparts. Polish writers and critics, regardless of their actual knowledge of life in Ireland, perceived something of themselves in Irish cultural activity. Nowaczyński's use of the term "Poles of the Western World" for the Irish speaks volumes about the aspirations of many writers of Young Poland. By projecting their own cultural work on to a celebrated cultural movement in Western Europe, Polish national aspirations could assume a certain degree of legitimacy. By the same token, Young Poland's interest in renewing Polish identity resulted in a great deal of introspection. The symbolic weight of Irish suffering, both in its political and religious dimensions, naturally harmonized with the self-image of many Polish writers.

Young Poland and Irish-Ireland, finally, reveal their greatest affinity in the role each movement played in sustaining the national task of achieving independence. Following World War I, both Poland and Ireland achieved a measure of independence for the first time in over a century. Without the exuberance and vitality of Young Poland and the Irish Revival, it is possible neither nation would have been prepared to make the difficult transitions necessary to become modern European nations. For many of the young Polish writers who initiated the Young Poland movement, the key trauma in the national memory was the failure of the 1863 Uprising. The last in a series of failed attempts at revolt in the nineteenth century, the so-called January Uprising was followed by a period of social and spiritual stagnation that lasted well into the 1880s. Young Poland, as a movement, was a conscious attempt to infuse national hopes with a new vitality. In Ireland, the fall of Charles Stewart Parnell in 1891 and the ever-growing shadow of England on Irish cultural life, created a void in Irish society that was filled by Irish writers and cultural activists hoping to maintain Irish national identity. On a greater scale, the cultural affinity of Young Poland and Irish-Ireland demonstrates that both the Poles and the Irish felt their cultures, and more important, their nations, were part of the larger European cultural fabric. Although shaken by the convulsions of the war, Europe survived, and then expanded, to include the fledging nations of Poland and Ireland. 